\title{
Development, validation, and application of an acetylcholinesterase-biosensor test for the direct detection of insecticide residues in infant food
}

Holger Schulze ${ }^{1}$, Ellen Scherbaum ${ }^{2}$, Michelangelo Anastassiades ${ }^{2}$, Sandra Vorlová ${ }^{1}$ Rolf D. Schmid ${ }^{1}$, Till T. Bachmann ${ }^{1^{*}}$

*Corresponding author:

${ }^{1}$ Institute of Technical Biochemistry

University of Stuttgart

Allmandring 31

D-70569 Stuttgart, Germany

Email: itbtba@itb.uni-stuttgart.de

${ }^{2}$ Chemisches und Veterinäruntersuchungsamt Stuttgart

Schaflandstr. 3/2

D-70736 Fellbach, Germany 


\begin{abstract}
A highly sensitive and rapid food-screening test based on disposable screen-printed biosensors was developed, which is suitable for monitoring infant food. The exposure of infants and children to neurotoxic organophosphates and carbamates is of particular concern because of their higher susceptibility to adverse effects. The European Union has therefore set a very low limit for pesticides in infant food which must not contain concentrations exceeding $10 \mu \mathrm{g} / \mathrm{kg}$ for any given pesticide. The maximum residue limit ( $M R L)$ has been set to be near the determination threshold that is typically achieved for pesticides with traditional analytical methods. The biosensor method could detect levels lower than $5 \mu \mathrm{g} / \mathrm{kg}$ and thus clearly fulfills the demands of the EU. To substantiate these measurements, recovery rates were determined and amounted on average to $104 \%$ in food. Matrix effects were eliminated by the introduction of a special electrode treatment. The test was compared with two traditional pesticide multiresidue analysis methods (GC/MS, LC/MS) using 26 fruit and vegetable samples from local markets and 23 samples of processed infant food from Germany, Spain, Poland and the USA. Three infant food samples exceeded the MRL of $10 \mu \mathrm{g} / \mathrm{kg}$ when analyzed by either biosensor test or multiresidue methods.
\end{abstract}

Keywords: acetylcholinesterase biosensor, organophosphate, carbamate, validation, food, infant food 


\section{Introduction}

Pesticides are widely used in agriculture to increase yield, control microorganisms, which might produce toxic or carcinogenic metabolites, and reduce the costs of food production. According to statistical data published by the Food and Agriculture Organization of the United Nations (FAO), more than 1.2 million metric tons of pesticides were sold to the agricultural sector world-wide in 1995 (FAOSTAT, 1995). These pesticides could be divided into $26 \%$ insecticides, $31 \%$ fungicides and $43 \%$ herbicides. The majority of the insecticides used were acetylcholinesterase inhibitors, $55 \%$ of them belonged to the group of organophosphates and $11 \%$ to carbamates, whereas the others were pyrethroids, chlorinated hydrocarbons or other insecticides. These pesticides are intended to kill living organisms, and a potential dose-related acute and chronic toxicity exists in humans (Jeyaratnam, 1990). Of particular concern is the exposure of infants and children to food contaminants because of their possible increased susceptibility to adverse effects (Larsen and Pascal, 1998; Koletzko et al., 1999). The toxicity of pesticides in infants and children may differ quantitatively and qualitatively from that in adults (Dencker and Ericsjsson, 1998; Ostergard and Knudsen, 1998; Schilter and Huggett, 1998; Karalliedde, 1999).

Considering the multitude of risks associated with pesticide intake by infants, the European Union has set a very low limit for pesticides in infant food. According to this regulation infant formulae must not contain residues of individual pesticides at levels exceeding $10 \mu \mathrm{g} / \mathrm{kg}(E C, 1999)$. This threshold has been set close to the value that can be analytically determined with traditional methods. In the USA, the 1996 Food Quality Protection Act mandated increased attention to the potential risks to infants and children from pesticide residues which resulted in a 10-fold safety factor for all pesticides to which children are exposed, unless the Environmental Protection 
Agency (EPA) can show that an adequate margin of safety is assured without it (FQPA, 1996; Scheuplein, 2000).

Consequently, there is a growing interest in fast and more sensitive detection systems. Traditional methods for insecticide detection are based on gas chromatography (GC) or high performance liquid chromatography (HPLC) coupled with mass selective detectors (MSD) (Martinez et al., 1992; Pylypiw, 1993). Depending on the food being investigated, e.g. citrus fruits, different multiresidue methods for the compound-specific detection of pesticides are available (Anastassiades and Scherbaum, 1997). The disadvantage of these methods is the relatively long assay time and their inherent restriction to a limited number of pesticides, which can be identified by the multiresidue methods. Hence, the possibility of detecting false negatives in unknown samples exists if not all pesticides are covered by the applied multiresidue method. As an alternative, acetylcholinesterase (AChE) inhibition tests, and the AChE-biosensors in particular, have been repeatedly described for use in insecticide detection (Guilbault and NgehNgwainbi, 1988; Palleschi et al., 1992; Skladal and Mascini, 1992; Mionetto et al., 1994; Saul et al., 1995; Evtugyn et al., 1996; Ghindilis et al., 1996; Makower et al., 1997; Abad et al., 1998; Bachmann and Schmid, 1999; Bachmann et al., 2000). As these tests can be used to determine the presence of organophosphates or carbamates as sum parameter of AChE inhibition with a high level of sensitivity in a relatively short time, AChE biosensors can prove useful in monitoring infant food, which must be free of pesticides and, in particular, free of neurotoxic compounds. Most of the AChE biosensors described so far are limited to analyzes based on aqueous solutions because of their possible susceptibility towards matrix effects. The few reports on cholinesterase-based biosensors applied to food testing either rely on laborious multi-step sample preparations or prove problematic because of the matrix 
effects which reduce the accuracy of the results (Saul et al., 1995; Palchetti et al., 1997; Skladal et al., 1997; Nunes et al., 1998; Nunes et al., 1999; Pogacnik and Franko, 1999). A recently developed test applying direct incubation in solvent extracts of food samples performed well in food with a high water content but showed reduced recovery rates of paraoxon in food with a low water content (Schulze et al., 2002).

In this paper, we describe an amperometric biosensor test based on screen-printed AChE biosensors which were described by Bachmann and Schmid (Bachmann and Schmid, 1999). The biosensor can be applied directly in food samples without the laborious pre-treatment of the samples. Matrix effects could be eliminated with special electrode treatment. In order to validate the performance of the method it was compared with traditional analytical methods used at the Chemical and Veterinary Official Laboratory (CVUA) Stuttgart ("Chemisches und Veterinär-Untersuchungsamt Stuttgart"), Germany. One of the methods applied involves classical solvent-based extraction and partitioning. The other method involves supercritical fluid extraction. Determination was performed by GC/MS and LC/MS. The developed biosensor method proved sensitive enough to be applied in the analysis of infant food samples.

\section{Experimental}

\subsection{Reagents and samples}

AChE (EC 3.1.1.7) from electric eel (Type $V-S, 970 \mathrm{U} / \mathrm{mg}$ ) was obtained from SigmaAldrich (Deisenhofen, Germany). Paraoxon (paraoxon-ethyl) and Tween-20 were purchased from Riedel de Haën (Seelze, Germany). Pesticide standards were purchased from Promochem (Wesel, Germany) or Riedel de Haën (Seelze, Germany). Insecticide stock solutions were prepared in ethanol. All other reagents 
were of analytical grade as supplied by Sigma-Aldrich (Deisenhofen, Germany). Hydromatrix $^{\circledR}$ no. 0019-8004 for SFE was obtained from Varian (Darmstadt, Germany). Acetonitrile, methanol, cyclohexane, isooctane, ethyl acetate and acetone were all of residue analysis grade.

Infant food samples were obtained from local stores in Germany, Spain, Poland and the USA. Five different German brands, one Polish brand (in four different flavors), two Spanish brands and two American brands were tested.

\subsection{Expression of human AChE synthetic gene in Pichia pastoris}

The following strategy (in brief) was used for cloning and expression of human AChE (huAChE) (Vorlová, S., Schmitt, J. and Schmid, R.D., in preparation): A synthetic gene of the huAChE was completely synthesized following the method of mutually priming long overlapping oligonucleotides. The nucleotide sequence was optimized for the expression in the yeast $P$. pastoris. The gene was inserted into the shuttle vector $\mathrm{pPICZ} \alpha \mathrm{A}$ under the control of the AOX1 promoter; transformation of yeast cells was performed by electroporation. Recombinant $P$. pastoris transformants producing acetylcholinesterase were grown according to the manufacturer's (Invitrogen, Carlsbad, CA, USA) protocol in glycerol-containing (1 \% (v/v)) BMGY media and induced in BMMY media, containing $0.5 \%(\mathrm{v} / \mathrm{v})$ methanol in agitated (200 rpm) shaking flasks. Every 24h, $0.5 \%(\mathrm{v} / \mathrm{v})$ of pure methanol was added to maintain induction, and an aliquot of the culture was withdrawn to monitor the expression level of huAChE in the cells and the culture supernatant.

\subsection{Biosensor measurement}

Disposable biosensors with immobilized electric eel and human AChE were produced following the screen-printing method suggested by Bachmann and Schmid (Bachmann and Schmid, 1999). In brief, thickfilm electrodes were printed on flexible 
polyvinylchloride sheets from SKK (Denzlingen, Germany) using a DEK 249 screen printer (DEK Ltd., Weymouth, England) and polyester screens $\left(45^{\circ}, 100 \mathrm{~T}\right)$ that were purchased from Steinmann $\mathrm{GmbH}$ (Stuttgart, Germany). Screen printing inks (Electrodag PF-410, Electrodag 423 SS, Electrodag 6037 SS) were obtained from Acheson (Scheemda, Netherlands). Ink for working electrodes contained 3\% (w/w) hydroxyethyl cellulose (HEC) and 15\% (w/w) 7,7,8,8,-tetracyanoquino-dimethane (TCNQ)-graphite (2,5\% TCNQ in T15 graphite from Lonza (Basel, Switzerland)). Marastar SR 057 purchased from Marabu (Tamm, Germany) was used as insulation ink. The electrodes were cured for 30 min at $90^{\circ} \mathrm{C}$ before enzyme immobilization. The enzyme printing ink contained $5 \%(\mathrm{w} / \mathrm{w})$ bovine serum albumine (Sigma, Deisenhofen Germany) and $1 \mathrm{U} / \mathrm{mL}$ human or electric eel AChE in $1 \%(\mathrm{w} / \mathrm{w})$ hydroxyethyl cellulose (Fluka, Buchs, Switzerland) aqueous solution. This solution was printed with the screen-printing device on top of the working electrodes. Immobilization by cross-linking was performed in glutaraldehyde vapor for $15 \mathrm{~min}$ at room temperature. Human AChE was directly used from the culture supernatant without further purification steps. All sensor experiments were carried out in a stirred buffer solution (0,01 M potassium phosphate buffer, 0,05 M NaCl, pH 7,5 (PBS)) at room temperature. Enzyme activity was determined by monitoring thiocholine formed by enzymatic hydrolysis of acetylthiocholine chloride $(1 \mathrm{mM})$. Thiocholine was determined by oxidation at $100 \mathrm{mV}$ versus $\mathrm{Ag} / \mathrm{AgCl}$. For use in the inhibition experiments, the biosensor was incubated with a sample for $30 \mathrm{~min}$ at room temperature in a non-stirred solution and percentage of inhibition was calculated after the measurement of residual activity. 


\subsection{Reactivation of AChE-activity}

To determine the AChE-activity reactivation rate, $1 \mathrm{mM}$ pyridine-2-aldoxime methochloride (2-PAM) in PBS was used as reactivating agent. The biosensor was incubated for $30 \mathrm{~min}$ in a stirred reactivation solution at room temperature. The final AChE activity was then measured in a buffer solution.

\subsection{Biosensor food test}

Food samples $(10 \mathrm{~g})$ were mixed with $10 \mathrm{~mL} 1 \mathrm{M}$ potassium phosphate buffer (PBS) $(\mathrm{pH} 7,5)$ to ensure a sufficient amount of water at a neutral $\mathrm{pH}$ value. The AChE biosensor was incubated in the food sample for $30 \mathrm{~min}$. Before measuring the activity of the enzyme in the buffer solution, the electrodes were placed in PBS containing 1 vol-\% Tween-20 for 15 min and then washed with pure PBS before measuring the initial AChE activity and after incubation in the food sample before measuring the residual AChE activity.

\subsection{Conventional analytical methods}

\subsubsection{Supercritical fluid extraction (SFE) method}

A representative sample portion of $7.5 \mathrm{~g}$ was weighed into a $100 \mathrm{~mL}$ beaker. Six $\mathrm{g}$ Hydromatrix $^{\circledR}$ (Varian, no. 0019-8004) was added and the mixture stirred intensively to achieve good homogeneity. An aliquot of $4.5 \mathrm{~g}$ (2.5 g sample) was transferred into the extraction thimble. To prevent particles from being extruded during extraction or depressurization, which could result in tube plugging, a fine grade glass wool paper was placed at either end of the extraction thimble.

The loaded thimbles were placed into a freezer immediately after filling and kept there until further processing because previous storage experiments had shown that some analytes (e.g. ethiofencarb, methiocarb, benfuracarb, furathiocarb, carbosulfan, 
dichlorvos) degraded significantly in the extraction cells when kept at room temperature (Anastassiades, in preparation). Freezing of the loaded thimbles (at $18^{\circ} \mathrm{C}$ ) efficiently prevented degradation.

A second $4.5 \mathrm{~g}$ aliquot of the sample/Hydromatrix ${ }^{\circledR}$ mixture was stored in a glass vial for further use in case the extraction had to be repeated.

Extraction of the samples by $\mathrm{SC}-\mathrm{CO}_{2}$ and reconstitution of the extracts in acetonitrile was performed automatically. The extraction conditions used are shown in Table 1.

\subsubsection{Liquid solvent based method}

A modified version of a multiresidue method was used to extract organophosphates and carbamates, which was developed at the CVUA Stuttgart for the analysis of pesticide residues in citrus fruits (Anastassiades and Scherbaum, 1997). After sample comminution, $20 \mathrm{~g}$ sample were extracted with $50 \mathrm{~mL}$ acetone with an UltraTurrax and filtrated. Water and $10 \mathrm{~mL}$ saturated $\mathrm{NaCl}$ solution was added to the extract. Two liquid-liquid partitioning steps were performed with $20 \mathrm{~mL}$ cyclohexane/ethyl acetate (1:1). The combined extracts were dried with $\mathrm{Na}_{2} \mathrm{SO}_{4}$ and concentrated, followed by reconstitution with acetonitrile to a defined volume of 10 $\mathrm{mL}$. Determination was performed with GC in SIM mode or LC/MS in ESI-positive mode.

\subsubsection{Measurement}

The instrumental conditions used during LC/MS in ESI (pos.) mode for the identification and quantification of the carbamates are listed in Table 2. An internal standard calibration was performed for quantification. Table 3 shows the target and qualifier ions used. Determination limits for the carbamates were $0.01 \mathrm{mg} / \mathrm{kg}$ or lower. Organophosphates were analyzed using GC-MS in single ion monitoring (SIM) mode in order to achieve good determination limits (HP 5890 Series II, auto sampler 7673, 
injector Gerstel CIS, solvent mode, detector HP 5970 MSD, equipped with uncoated pre-column $3 \mathrm{~m} \times 0.25 \mathrm{~mm}$, press fit connection to the analytical column HP5MS, 30 $\mathrm{m} \times 0.25 \mathrm{~mm}, 0.25 \mu \mathrm{m}$, carrier gas helium constant flow). Table 4 shows the spectrum of the compounds and the target and qualifier ions used for SIM mode. The determination limit was $0.01 \mathrm{mg} / \mathrm{kg}$ or lower for most compounds (see also Table 4).

\section{Results and discussion}

\subsection{Preventing matrix effects with electrode modification}

To develop a simple assay system, it was attempted to measure untreated food with the AChE electrode directly. Aliquots of orange juice, peach and apple infant food were used for this purpose and a high AChE inhibition was observed in all cases (Table 5). An expected reason for the high inhibition rate was the low natural $\mathrm{pH}$ value of fruits: adjustment to a neutral $\mathrm{pH}$ reduced the inhibition rate from $56 \%$ to 41 $\%$ in the case of orange juice. AChE inhibition could not be reactivated with 2-PAM, a nucleophilic oxime. Oxime treatment removes the phosphate group from the serine residue of the inhibited AChE. It can therefore be concluded that the AChE inhibition did not result from the presence of organophosphates or carbamates in the food samples. In addition, it was observed that during activity measurements the thickfilm electrodes required much longer equilibration times when they were previously incubated in food samples. The equilibration time denotes the time that is required until a constant current is reached and the substrate can be added to the buffer solution. We believe that these problems are caused by matrix particles that are bound to the surface of the electrodes. These matrix particles could not be removed from the electrode surface by washing it with either buffer or water. One possibility to prevent these matrix effects is to add an extraction step in the protocol followed by 
incubation in the solvent extract, as described by Schulze and coworkers (Schulze et al., 2002). In the present study, matrix effects were avoided by treating the electrodes with a 1 vol-\% Tween-20 solution in phosphate-buffer $(\mathrm{pH} 7,5)$ after their incubation in the food samples. The use of this detergent solution solved virtually all the previously described problems. Unspecific inhibition was no longer observed and the time required for equilibration took approximately 10 minutes. The detergent solution (1 vol-\% Tween-20) itself did not lead to a decrease in AChE activity.

\subsection{Test performance}

The proper performance of the test was verified by analyzing several food samples to which different amounts of paraoxon-ethyl in the concentration range between 5 and $20 \mu \mathrm{g} / \mathrm{kg}$ were added. The inhibition of electric eel AChE (eeAChE), caused by the incubation in the spiked food, was compared with the inhibition that was observed when equivalent paraoxon concentrations were present in the buffer-solution. Recovery rates were calculated out of the difference of these two inhibition values. Figure 1 shows the AChE inhibition values of spiked peach-based infant food. The inhibition values correlated well with the standard inhibition curve in buffer solution. The recovery rate for paraoxon-ethyl in peach infant food was $101 \%$. Experiments with apple-based infant food yielded a recovery rate of $106 \%$ (Figs. 2). All recovery rates met the legal requirements of a value between 70 and $110 \%$ (EC, 1997). The analysis of spiked food samples showed an acceptable reproducibility even at very low inhibitor concentrations. The coefficient of variation was on average $8 \%$ and $9 \%$ in the case of peach and apple infant food.

The determination limit in food was less than $5 \mu \mathrm{g} / \mathrm{kg}$ paraoxon with eeAChE. The signal- to-noise ratio at a concentration of $5 \mu \mathrm{g} / \mathrm{kg}$ paraoxon $\left(1,8 \times 10^{-8} \mathrm{~mol} / \mathrm{L}\right)$ in apple and peach-based infant food was well above $3: 1$ (e.g. $8: 1$ in the case of 
peach-based infant food). Lower paraoxon concentrations were not tested in food samples. The determination limit was similar to that measured with conventional analytical methods and could be reduced using AChEs from other sources, such as e.g. Drosophila melanogaster AChE or genetically engineered AChE variants (Villatte et al., 1998; Schulze et al., in press).

With respect to pesticides the developed test has several advantages over standard analytical methods and previously described biosensor tests. Using this test, samples can be analyzed within approximately 90 min, which means that at least four to five hours can be saved with the test compared to the commonly used multiresidue methods (Anastassiades and Scherbaum, 1997). The handling of the samples is much easier than with traditional methods since the test does not involve complicated extraction, cleanup and measurement steps which often require well-trained personnel and sophisticated equipment. This test also avoids the use of any organic solvent and involves no pre-concentration step. In contrast to other biosensor tests, which showed reduced recovery rates in food (in most cases below 70 \%) (Skladal et al., 1997; Nunes et al., 1998; Nunes et al., 1999; Pogacnik and Franko, 1999), the accuracy of the recoveries is very high, even at very low neurotoxin concentrations. The main advantage of the biosensor tests over conventional methods is that principally all AChE-inhibiting compounds can be detected. However, it is only possible to measure a sum parameter of $\mathrm{AChE}$ inhibition; qualitative or quantitative information about the single compounds cannot be obtained. In combination with traditional multiresidue methods, the biosensor test can nevertheless be applied as a pre-screening test to discriminate between samples that do or do not contain AChE inhibitors. Should AChE inhibitors be targeted, the biosensor test would help to increase the number of tested samples. To minimize false positive results, it is advisable to set an inhibition threshold for each commodity (action level). 


\subsection{Validation with standard analytical methods}

To validate the biosensor method, 26 fruit and vegetable samples were tested which were previously analyzed with traditional multiresidue methods. Two types of AChEs were used for these measurements: electric eel and recombinant human AChE. Ratios of AChE inhibition of these two enzymes were compared with ratios of bimolecular rate constants of AChE inhibition (ki). The results are shown in Table 6 . Only a single insecticide could be detected in the first five samples with the multiresidue method. A pear sample, which contained $22 \mu \mathrm{g} / \mathrm{kg}$ carbofuran, led to 48 $\%$ eeAChE inhibition and to $25 \%$ huAChE inhibition. The different extent of enzyme inhibition results from the differences in the ki values of eeAChE and huAchE towards these neurotoxins. The low inhibition observed with the apple sample containing 158 $\mu \mathrm{g} / \mathrm{kg}$ pirimicarb was expected because of the small ki-values of $1,0 \cdot 10^{3} \mathrm{M}^{-1} \mathrm{~min}^{-1}$ and 1,0 $10^{4} \mathrm{M}^{-1} \mathrm{~min}^{-1}$, respectively. The ratios of enzyme inhibition of the first four samples $(1,9 / 0,8 / 0,3 / 0,9)$ corresponded with the expected values calculated from the ki values $(3,6 / 1,1 / 0,1 / 0,8)$. To the best of our knowledge, ki-values have so far not been published for methamidophos.

The next five samples (Table 6) contained a mixture of different neurotoxins. Pears were contaminated with $50 \mu \mathrm{g} / \mathrm{kg}$ carbaryl, $17 \mu \mathrm{g} / \mathrm{kg}$ chlorpyriphos ethyl and $20 \mu \mathrm{g} / \mathrm{kg}$ chlorpyriphos methyl. This pear sample caused a $71 \%$ inhibition of eeAChE. The reason for the observed inhibition caused by the next three samples (lemon, orange and grapefruit) could not finally be clarified. One possible explanation is that small amounts of the present phosphorothionates which do not inhibit AChE at this concentrations are spontaneously oxidized to the corresponding oxo-variants, e.g. by the impact of UV light (Chambers and Levi, 1992). Finally, no pesticides could be detected with the GC-MS method in a number of samples. Most of these did not lead to any or only slight inhibition of the applied acetylcholinesterases. Others, however, 
inhibited the enzymes significantly (more than $10 \%$ ). A possible explanation for this observation is the limited analyte spectrum of the GC-MS analysis. The multiresidue methods usually used to examine fruits and vegetables cover just 200 of about 500 applied pesticides and many AChE inhibitors are not included.

The correct functioning of the biosensor test could be confirmed in many different types of fruits and vegetables, from the very fibrous pea or asparagus to several kinds of citrus fruits. The use of a multi-electrode system employing two different AChEs, which usually have different inhibition constants towards the tested organophosphates and carbamates, gives additional certainty about the observation that the inhibition is caused by neurotoxins and not by some kinds of matrix effects. The use of human AChE can also help to estimate the potential health risk of the analyzed food to man.

\subsection{Infant food analysis}

Processed infant food samples from Germany, Spain, Poland and the USA were analyzed with the AChE-biosensor test and with the multiresidue method involving LC-MS and GC-MS analysis. In total, 23 different types of infant food were tested: 13 different flavors of four German brands, four flavors of two Spanish brands, four flavors of one Polish brand and two flavors of two American brands. The biosensor measurements were again performed with a two-electrode system employing electric eel and human AChE. Since the concentrations of possible contaminants in infant food are typically very low, an additional proof of evidence for the functionality of the biosensor was added to the analytical procedure. The determination of the reactivation rate of the inhibited enzyme after reaction with a nucleophilic oxime which reconstitutes the active AChE turned out to be an appropriate way to discriminate between infant food contaminated with neurotoxins and infant food free 
of cholinesterase-inhibitors. But reactivation of inhibited AChE is only possible before "aging" (loss of an alkyl residue) of the phosphoryl moiety attached to the active site serine of AChE. This aging process depends on the kind of organophosphate which reacts with AChE, e.g. methoxy groups age more rapidly than ethoxy groups (Chambers and Levi, 1992).

Of 23 tested infant food samples, 13 caused AChE inhibition, which could be at least partially reactivated (see Table 7). The multiresidue method detected pesticides in 11 of the samples tested. Two samples led to reactivalable AChE inhibition but no neurotoxins were detected by LC-MS or GC-MS. In this case, the restriction of the standard detection methods to a limited number of pesticides must be taken into account. The other 10 tested infant food samples did not show any reactivalable AChE inhibition. These samples were not analyzed with the multiresidue methods. Of the 14 detected pesticides, the following proved to be AChE inhibitors: pirimicarb, ethiofencarb, carbaryl, methiocarb and paraoxon. Carbaryl was the most commonly found pesticide.

Three violations of the maximum residue limit of $10 \mu \mathrm{g} / \mathrm{kg}$ valid in the EU for infant food were observed. One batch of the German banana-tangerine-pear infant food contained $20 \mu \mathrm{g} / \mathrm{kg}$ pirimicarb and $50 \mu \mathrm{g} / \mathrm{kg}$ ethiofencarb. The analysis of this sample with huAChE resulted in $10 \%$ inhibition, which could be reactivated to an extent of $68 \%$. In samples of an older batch of the same brand no pesticides were detected by either of the two methods. A German fruit salad infant food contained $10 \mu \mathrm{g} / \mathrm{kg}$ carbaryl. Seventy $\mu \mathrm{g} / \mathrm{kg}$ propiconazol and $20 \mu \mathrm{g} / \mathrm{kg}$ esfenvalerat were found in an American peach infant food sample. These two compounds are no cholinesterase inhibitors, but it is not unlikely that also pesticides, in addition to those detected, might be present in the sample. 
Concerning the detection frequency of pesticides in infant food (EWG, 1995), a study carried out by the Environmental Working Group (EWG), an American non-profit environmental research organization, came to similar results. Of 72 infant food samples from the three largest American infant food producers, more than half (53 $\%)$ contained detectable levels of pesticides. Two or more pesticides were found in $18 \%$ of the samples. Among the 16 detected pesticides were 9 organophosphates or carbamates. A test of 155 infant food samples conducted with the commercially available Charm Pesticide Test, which is also based on cholinesterase-inhibition, resulted in $14 \%$ positive samples (Saul et al., 1995). Carbaryl was also the most frequently found pesticide in this study. This test has the disadvantage that it requires a laborious sample pre-treatment protocol including the extraction with organic solvents and subsequent re-dissolving in water.

The applicability of the new biosensor test for monitoring infant food could be shown in the present study. Good correlation was observed between the results obtained with the biosensor test and those with the GC-MS and LC-MS. The biosensor test has the advantage over standard analytical methods that the risk of false negative results of the particularly dangerous group of organophosphates and carbamates is minimized substantially. In contrast to the Charm Pesticide Test it requires less working steps and does not require the use of organic solvents.

\section{Conclusion and outlook}

A biosensor test for the direct detection of organophosphates and carbamates in food was developed which requires no extraction or pre-concentration steps. Matrix effects could be avoided by the introduction of an electrode pre-treatment method. The test showed excellent recovery rates with acceptable levels of reproducibility even at trace concentrations. Validation was successfully performed by comparing the test 
results of real food samples with the conventional multiresidue methods applied at the CVUA Stuttgart. The applicability was proven by analyzing infant food samples. To increase the analyte spectrum of the biosensor test, a combination of different and more sensitive AChE variants could be applied in a multisensor array. It would also be desirable to add a method for the detection of phosphorothionates in food to the test protocol. Currently work is under way to achieve these requirements.

\section{Acknowledgement}

The authors would like to thank the European Union for financial support under project ACHEB (QLK30-2000-00650). 


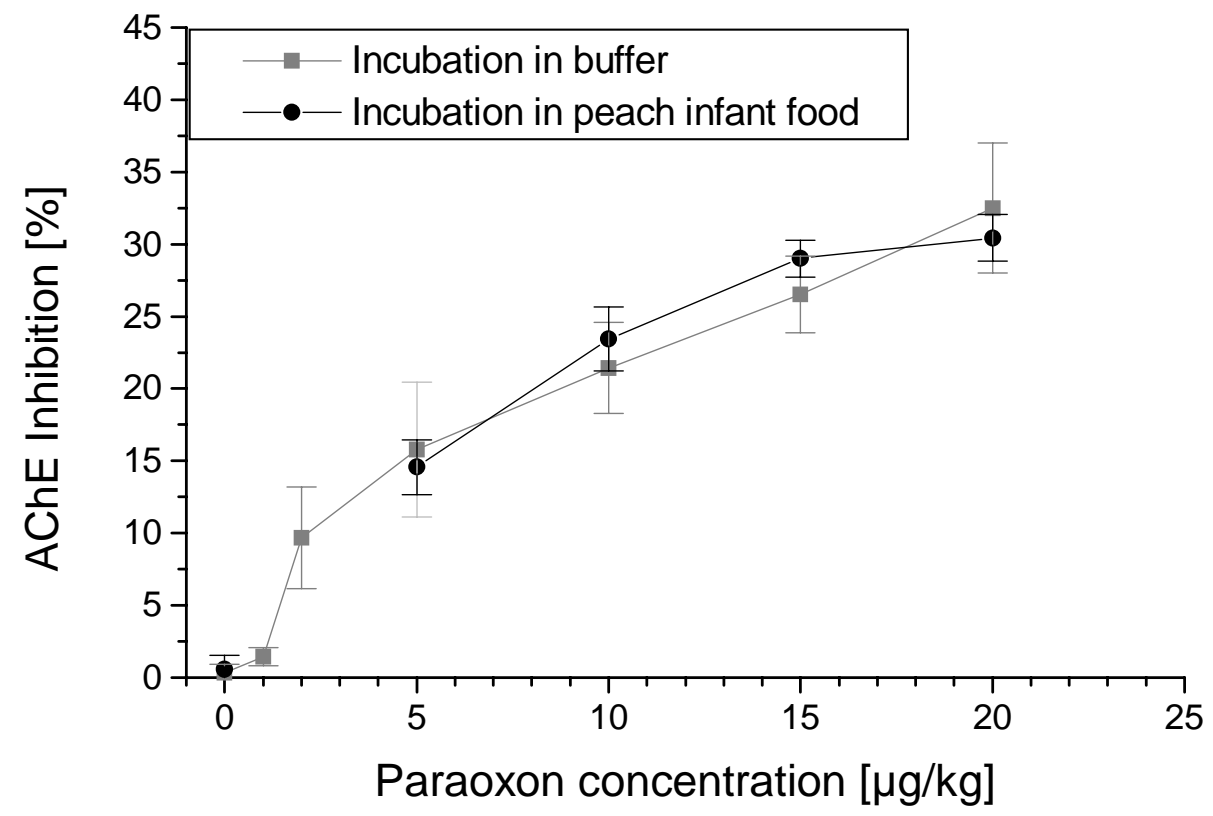

Figure 1: 


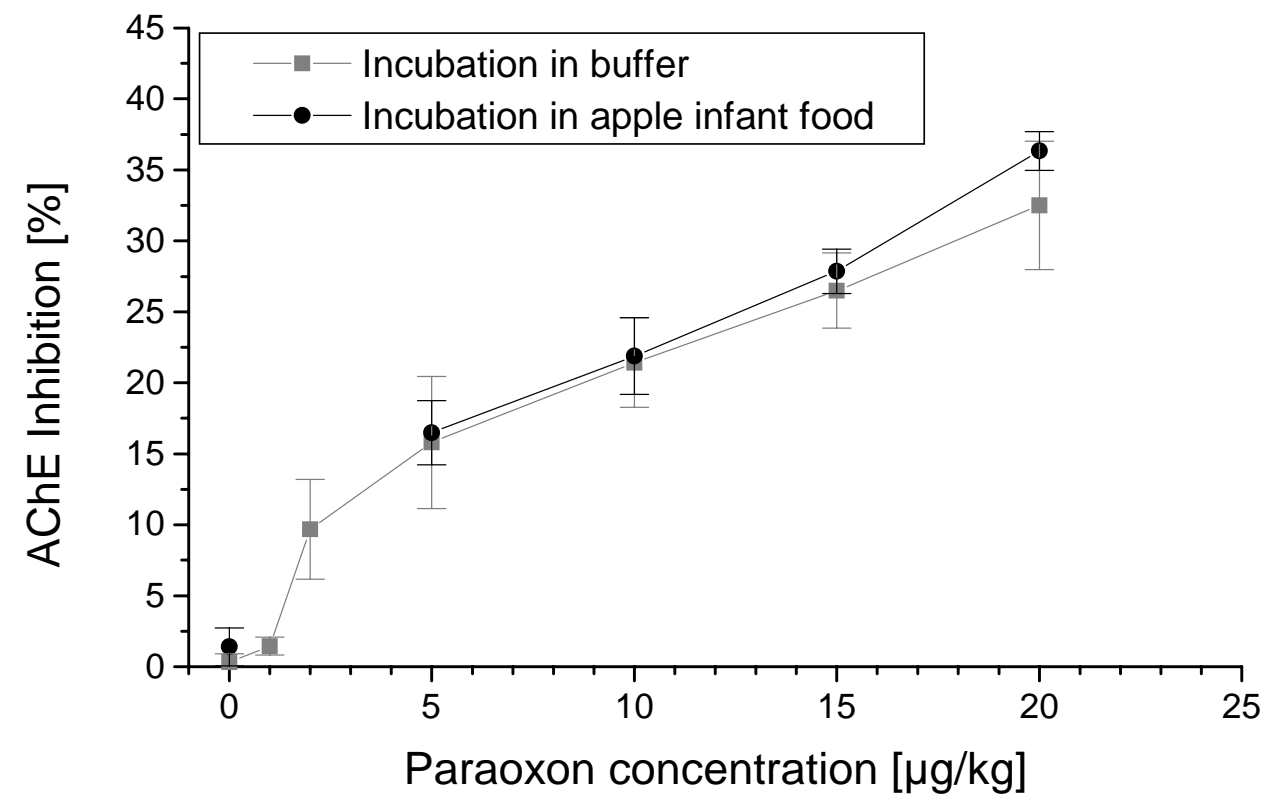

Figure 2: 
Table 1: SFE parameters for HP 7680T

\begin{tabular}{ll}
\hline Extraction pressure & $329 \mathrm{bar}$ \\
\hline Extraction temperature & $55^{\circ} \mathrm{C}$ \\
$\mathrm{CO}_{2}$-density & $0.89 \mathrm{~g} / \mathrm{mL}$ \\
Static extraction time & $2 \mathrm{~min}$ \\
Dynamic extraction time & $25 \mathrm{~min}$ \\
$\mathrm{CO}_{2}$-flow & $1.8 \mathrm{~mL} / \mathrm{min}$ \\
Trap material & $\mathrm{ODS}, 10^{\circ} \mathrm{C}$ during extraction, $40^{\circ} \mathrm{C}$ during elution \\
Elution solvent & acetonitrile $(2 \times 1.5 \mathrm{~mL}$, flow $0.5 \mathrm{~mL} / \mathrm{min})$ \\
Solvent for trap clean-up & cyclohexane $/$ ethyl acetate $1: 1(4 \mathrm{~mL}$, flow $0.8 \mathrm{~mL} / \mathrm{min})$ \\
Solvent for trap reconditioning & acetonitrile $(3 \mathrm{~mL}$, flow $0.8 \mathrm{~mL} / \mathrm{min})$ \\
\hline
\end{tabular}


Table 2: Instrumental conditions used at LC/MS

ESI (pos.) mode

LC Parameters:

- LC-MSD HP 1100 series

- column: 2.1 x 150 mm, $3.5 \mu$, ZORBAX XDB C-18

- injection volume: $5 \mu \mathrm{L}$

- mobile phases:

A: $5 \mathrm{mM}$ aqueous $\mathrm{CH}_{3} \mathrm{COONH}_{4}$ : acetonitrile (90:10)

B: $5 \mathrm{mM}$ aqueous $\mathrm{CH}_{3} \mathrm{COONH}_{4}$ : acetonitrile (10:90)

- flow $0.3 \mathrm{~mL} / \mathrm{min}$

- gradient: $30 \% \mathrm{~B} \rightarrow 90 \% \mathrm{~B}$ in $8 \mathrm{~min}$, temp.: $50^{\circ} \mathrm{C}$

MSD Parameters:

- API electrospray

- Variable fragmentor voltage, see Table 3

- drying gas: nitrogen $10 \mathrm{~L} / \mathrm{min}, 300{ }^{\circ} \mathrm{C}$ Vcap: $4000 \mathrm{~V}$ 
Table 3: LC/MS target and qualifier masses and corresponding fragmentor voltages (Frag. [V]) for carbamates

\begin{tabular}{|c|c|c|c|c|c|c|}
\hline $\begin{array}{l}\text { N-Methyl- } \\
\text { Carbamate }\end{array}$ & $\mathrm{M}+1$ & M-56 & $\begin{array}{c}\mathrm{M}+18 \\
\text { plus } \mathrm{NH}_{4}^{+} \\
\text {(Frag. [V]) }\end{array}$ & $\begin{array}{c}\mathrm{M}+23 \\
\text { plus } \mathrm{Na}^{+} \\
\text {(Frag. [V]) }\end{array}$ & $\begin{array}{c}\text { Other } \\
\text { ions } \\
\text { (Frag. [V]) }\end{array}$ & $\begin{array}{c}\text { Determination } \\
\text { limit } \\
{[\mathrm{mg} / \mathrm{kg}]}\end{array}$ \\
\hline Aldicarb & $213(30)$ & - & $208(20)$ & & $116(50)$ & 0,005 \\
\hline Aldicarb & & & & & & \\
\hline $\begin{array}{l}\text { Sulfon } \\
\text { (Aldoxycarb) } \\
\text { Aldicarb }\end{array}$ & $223(65)$ & $166(100)$ & $240(30)$ & 245 (100) & & 0,01 \\
\hline Sulfoxid & 207 (40) & - & $224(20)$ & $229(75)$ & $\begin{array}{c}132(65) \\
166(100)\end{array}$ & 0,01 \\
\hline Aminocarb & $209(40)$ & $152(90)$ & & & & 0,005 \\
\hline Bendiocarb & $224(50)$ & $167(100)$ & $241(15)$ & & 109 (100) & 0,01 \\
\hline Carbanolat & $214(50)$ & $157(90)$ & & & & 0,01 \\
\hline Carbaryl & $202(50)$ & $145(100)$ & $219(70)$ & $224(60)$ & & 0,01 \\
\hline Carbofuran & $222(50)$ & $165(90)$ & & & $123(140)$ & 0,005 \\
\hline Dioxacarb & $224(30)$ & $167(65)$ & & & $123(90)$ & 0,01 \\
\hline Ethiofencarb & 226 (30) & $169(55)$ & $243(10)$ & & $\begin{array}{l}164(70) \\
107(90)\end{array}$ & 0,01 \\
\hline $\begin{array}{l}\text { Ethiofencarb } \\
\text { Sulfon }\end{array}$ & - & $201(50)$ & & & $\begin{array}{l}218(30) \\
223(60) \\
107(80)\end{array}$ & 0,01 \\
\hline $\begin{array}{l}\text { Ethiofencarb } \\
\text { Sulfoxid }\end{array}$ & - & $185(30)$ & & & $\begin{array}{l}207(50) \\
107(65)\end{array}$ & 0,01 \\
\hline Fenobucarb & $208(50)$ & $152(90)$ & 225 (15) & & & 0,002 \\
\hline Isoprocarb & $194(60)$ & $137(80)$ & & & $152(90)$ & 0,005 \\
\hline $\begin{array}{l}\text { Landrin } \\
(2,4,5- \\
\text { Trimethacarb) }\end{array}$ & $194(50)$ & $137(100)$ & $211(20)$ & & & 0,002 \\
\hline
\end{tabular}




\begin{tabular}{|c|c|c|c|c|c|c|}
\hline $\begin{array}{l}\text { N-Methyl- } \\
\text { Carbamate }\end{array}$ & $\begin{array}{c}\mathrm{M}+1 \\
\text { (Frag. [V]) }\end{array}$ & $\begin{array}{c}\text { M-56 } \\
\text { (Frag. [V]) }\end{array}$ & $\begin{array}{c}\mathrm{M}+18 \\
\text { plus } \mathrm{NH}_{4}^{+} \\
\text {(Frag. [V]) }\end{array}$ & $\begin{array}{c}\mathrm{M}+23 \\
\text { plus } \mathrm{Na}^{+} \\
\text {(Frag. [V]) }\end{array}$ & $\begin{array}{c}\text { Other } \\
\text { ions } \\
\text { (Frag. [V]) }\end{array}$ & $\begin{array}{c}\text { Determination } \\
\text { limit } \\
{[\mathrm{mg} / \mathrm{kg}]}\end{array}$ \\
\hline \multicolumn{7}{|l|}{ Methiocarb } \\
\hline & $\begin{array}{c}226(20- \\
70)\end{array}$ & $169(90)$ & & & $\begin{array}{l}121(110) \\
107(110)\end{array}$ & 0,005 \\
\hline Methiocarb & & & & & $218(25)$ & \\
\hline Sulfon & $258(70)$ & 201 (100) & & & $\begin{array}{l}122(100) \\
107(110)\end{array}$ & 0,01 \\
\hline Methiocarb & & & & & $170(140)$ & \\
\hline Sulfoxid & $\begin{array}{c}242(80- \\
90)\end{array}$ & 185 (115) & & & $\begin{array}{c}122(140) \\
106(10)\end{array}$ & 0,005 \\
\hline Methomyl & $163(40)$ & $106(80)$ & & $185(80)$ & & 0,005 \\
\hline Metolcarb & & & & & & \\
\hline & $166(50)$ & $109(100)$ & $183(10)$ & & & 0,005 \\
\hline Oxamyl & $220(40)$ & - & 237 (10) & $242(80)$ & & 0,01 \\
\hline Promecarb & $208(50)$ & $151(100)$ & $225(10)$ & & $109(100)$ & 0,002 \\
\hline Propoxur & $210(25)$ & $153(70)$ & 227 (10) & & $\begin{array}{c}111(100) \\
168(70)\end{array}$ & 0,005 \\
\hline & & Pre & cursor Pesti & ides & & \\
\hline Thiodicarb & $355(30)$ & - & & & $\begin{array}{l}193(60) \\
149(70) \\
108(90)\end{array}$ & 0,005 \\
\hline Benfuracarb & $411(50)$ & - & & $433(130)$ & $\begin{array}{c}190(90) \\
195(130)\end{array}$ & 0,005 \\
\hline Furathiocarb & & - & & 405 (150) & $\begin{array}{l}252(110) \\
195(130)\end{array}$ & 0,005 \\
\hline Carbosulfan & $381(80)$ & - & & $\begin{array}{l}419(90) \\
\text { plus } \mathrm{K}^{+}\end{array}$ & $\begin{array}{l}160(120) \\
118(130) \\
195(130)\end{array}$ & 0,005 \\
\hline
\end{tabular}


Table 4: List of organophosphates analyzed by GC-MS

\begin{tabular}{|c|c|c|c|c|c|}
\hline \multirow{2}{*}{$\begin{array}{l}\text { Organophosphate } \\
\text { Acephate }\end{array}$} & \multicolumn{4}{|c|}{ Target and qualifier ions } & \multirow{2}{*}{$\begin{array}{c}\text { Determination } \\
\text { limit } \\
{[\mathrm{mg} / \mathrm{kg}]}\end{array}$} \\
\hline & 136 & 94 & 125 & & \\
\hline Azinphos-methyl & 160 & 132 & 77 & & 0,02 \\
\hline Bromophos & 331 & 329 & 333 & 125 & 0,001 \\
\hline Bromophos-ethyl & 359 & 303 & 357 & 301 & 0,002 \\
\hline Chlorfenvinphos & 323 & 267 & 269 & & 0,001 \\
\hline Chlorpyrifos & 197 & 199 & 314 & & 0,001 \\
\hline Chlorpyrifos-methyl & 286 & 288 & 125 & 109 & 0,001 \\
\hline Demeton-S-methyl & 88 & 109 & 142 & 230 & 0,01 \\
\hline Dichlorvos & 222 & 220 & 185 & 187 & 0,01 \\
\hline Dicrotophos & 237 & 192 & 193 & & 0,01 \\
\hline Dimethoat & 125 & 93 & 229 & & 0,01 \\
\hline Disulfoton & 274 & 142 & 186 & 88 & 0,002 \\
\hline Ethion & 384 & 231 & 153 & & 0,001 \\
\hline Ethoprophos & 242 & 200 & 158 & 139 & 0,002 \\
\hline Etrimfos & 292 & 277 & 181 & 153 & 0,001 \\
\hline Fenamiphos & 303 & 288 & 260 & 217 & 0,001 \\
\hline Fenchlorphos & 285 & 125 & 287 & 241 & 0,01 \\
\hline Fenitrothion & 277 & 125 & 260 & & 0,002 \\
\hline Fenthion & 278 & 125 & 169 & & 0,002 \\
\hline Fonofos & 246 & 137 & 109 & & 0,001 \\
\hline Isofenphos & 213 & 255 & 121 & & 0,002 \\
\hline Malaoxon & 268 & 239 & 195 & 127 & 0,01 \\
\hline Malathion & 173 & 125 & 127 & & 0,001 \\
\hline Methamidophos & 126 & 94 & 95 & 141 & 0,01 \\
\hline Methidathion & 145 & 85 & 125 & & 0,005 \\
\hline Mevinphos & 192 & 109 & 164 & 127 & 0,01 \\
\hline Monocrotophos & 223 & 192 & 193 & & 0,01 \\
\hline Omethoate & 156 & 110 & 79 & & 0,01 \\
\hline Paraoxon & 275 & 247 & 220 & 149 & 0,01 \\
\hline Paraoxon-methyl & 247 & 230 & 200 & 109 & 0,02 \\
\hline Parathion & 291 & 155 & 235 & & 0,001 \\
\hline Parathion-methyl & 263 & 125 & 109 & 233 & 0,001 \\
\hline Phorate & 260 & 231 & 121 & 75 & 0,001 \\
\hline Phosalone & 367 & 184 & 182 & 121 & 0,002 \\
\hline Phosmet & 160 & 317 & 133 & & 0,005 \\
\hline Phosphamidon & 264 & 127 & 138 & & 0,01 \\
\hline
\end{tabular}


Determination

\begin{tabular}{|c|c|c|c|c|c|}
\hline \multirow{2}{*}{$\begin{array}{l}\text { Organophosphate } \\
\text { Pirimiphos-methyl }\end{array}$} & \multicolumn{4}{|c|}{ Target and qualifier ions } & \multirow{2}{*}{$\begin{array}{r}\begin{array}{c}\text { limit } \\
{[\mathrm{mg} / \mathrm{kg}}\end{array} \\
0,001\end{array}$} \\
\hline & 290 & 305 & 276 & 233 & \\
\hline Profenofos & 208 & 337 & 339 & 139 & 0,005 \\
\hline Prothiofos & 309 & 267 & 311 & & 0,001 \\
\hline Pyrazophos & 221 & 232 & 265 & 373 & 0,005 \\
\hline Pyridaphenthion & 340 & 199 & 188 & & 0,002 \\
\hline Quinalphos & 146 & 298 & 156 & & 0,002 \\
\hline Tolylfluanid & 238 & 240 & 181 & & 0,002 \\
\hline Sulfotep & 322 & 266 & 202 & 294 & 0,001 \\
\hline Terbufos & 288 & 231 & 186 & 153 & 0,002 \\
\hline Tolclofos-methyl & 265 & 267 & 125 & 250 & 0,001 \\
\hline Triazophos & 257 & 161 & 162 & & 0,005 \\
\hline Trichlorfon & 221 & 145 & 109 & 147 & 0,02 \\
\hline
\end{tabular}


Table 5: Effects of untreated food samples at natural and neutral $\mathrm{pH}$ values on the activity of electric eel AChE in comparison to effects after Tween-20 treatment (unspecific inhibition):

\begin{tabular}{lccc}
\hline & \multicolumn{3}{c}{ AChE Inhibition [\%] } \\
\hline & $\mathrm{pH} \mathrm{4}$ & $\mathrm{pH} 7$ & Tween-20 \\
& & & $\mathrm{pH} 7$ \\
Apple juice & 18 & 10 & 3 \\
Orange juice & 56 & 41 & 2 \\
Peach infant food & 21 & 16 & 1 \\
Apple infant food & 19 & 12 & 1 \\
\hline
\end{tabular}


Table 6: Validation of the biosensor test with standard analytical methods

\begin{tabular}{|c|c|c|c|c|c|c|c|}
\hline Sample & GC-MS & $\begin{array}{l}\mathrm{l}_{\mathrm{ee}} \\
\text { [\%] }\end{array}$ & $\begin{array}{l}\mathrm{I}_{\mathrm{hu}} \\
{[\%]}\end{array}$ & $\mathrm{I}_{\mathrm{ee}} / \mathrm{I}_{\mathrm{hu}}$ & $\begin{array}{l}\mathrm{ki}_{\mathrm{ee}} \\
{\left[\mathrm{M}^{-1} \mathrm{~min}^{-1}\right]} \\
{[1][2]}\end{array}$ & $\begin{array}{l}\mathrm{ki}_{\mathrm{hu}} \\
{\left[\mathrm{M}^{-1} \mathrm{~min}^{-1}\right]} \\
{[1][2]}\end{array}$ & $\begin{array}{l}\mathrm{ki} \mathrm{iee}_{\mathrm{e}} / \\
\mathrm{ki} \mathrm{i}_{\mathrm{hu}}\end{array}$ \\
\hline Pear & $22 \mu \mathrm{g} / \mathrm{kg}$ Carbofuran & 48 & 25 & 1,9 & $2,9 \cdot 10^{6}$ & $0,8 \cdot 10^{6}$ & 3,6 \\
\hline Cherry & $40 \mu \mathrm{g} / \mathrm{kg}$ Methiocarb & 11 & 14 & 0,8 & $1,0 \cdot 10^{5}$ & $0,9 \cdot 10^{5}$ & 1,1 \\
\hline Apple & 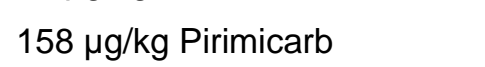 & 1 & 4 & 0,3 & $1,0 \cdot 10^{3}$ & $1,0 \cdot 10^{4}$ & 0,1 \\
\hline Apple & $40 \mu \mathrm{g} / \mathrm{kg}$ Dichlorvos & 33 & 38 & 0,9 & $4,2 \cdot 10^{4}$ & $5,2 \cdot 10^{4}$ & 0,8 \\
\hline Paprika & $110 \mu \mathrm{g} / \mathrm{kg}$ Methamidophos & 24 & 37 & 0,6 & & & \\
\hline Apple & 114 нg/kg Carbaryl & 21 & n.a. & & $6,6 \cdot 10^{4}$ & $2,7 \cdot 10^{4}$ & 2,4 \\
\hline \multirow[t]{3}{*}{ Pear } & 50 g/kg Carbaryl & 71 & n.a. & & $6,6 \cdot 10^{4}$ & $2,7 \cdot 10^{4}$ & 2,4 \\
\hline & $17 \mu \mathrm{g} / \mathrm{kg}$ Chlorpyrifos-ethyl* & & & & $1,8 \cdot 10^{6}$ & $0,6 \cdot 10^{7}$ & 0,3 \\
\hline & 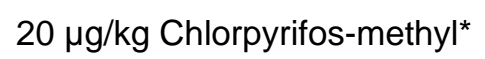 & & & & $0,7 \cdot 10^{6}$ & $2,2 \cdot 10^{6}$ & 0,3 \\
\hline \multirow[t]{2}{*}{ Lemon } & $123 \mu \mathrm{g} / \mathrm{kg}$ Chlorpyrifos-ethyl ${ }^{*}$ & 18 & 27 & 0,7 & $1,8 \cdot 10^{6}$ & $0,6 \cdot 10^{7}$ & 0,3 \\
\hline & $813 \mu \mathrm{g} / \mathrm{kg}$ Methidathion* & & & & $0,6 \cdot 10^{6}$ & $0,9 \cdot 10^{5}$ & 6,7 \\
\hline \multirow[t]{2}{*}{ Lemon } & 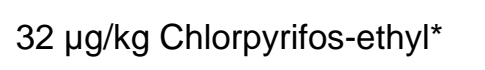 & 27 & 31 & 0,9 & $1,8 \cdot 10^{6}$ & $0,6 \cdot 10^{7}$ & 0,3 \\
\hline & $2470 \mu \mathrm{g} / \mathrm{kg}$ Methidathion* & & & & $0,6 \cdot 10^{6}$ & $0,9 \cdot 10^{5}$ & 6,7 \\
\hline \multirow[t]{3}{*}{ Orange } & $5 \mu \mathrm{g} / \mathrm{kg}$ Chlorpyrifos-ethyl* & 21 & 32 & 0,7 & $1,8 \cdot 10^{6}$ & $0,6 \cdot 10^{7}$ & 0,3 \\
\hline & 1060 hg/kg Methidathion* & & & & $0,6 \cdot 10^{6}$ & $0,9 \cdot 10^{5}$ & 6,7 \\
\hline & $838 \mu \mathrm{g} / \mathrm{kg}$ Malathion* & & & & $1,7 \cdot 10^{6}$ & $3,3 \cdot 10^{5}$ & 5,2 \\
\hline \multirow[t]{2}{*}{ Grapefruit } & $180 \mu \mathrm{g} / \mathrm{kg}$ Chlorpyrifos-ethyl* & 23 & 18 & 1,3 & $1,8 \cdot 10^{6}$ & $0,6 \cdot 10^{7}$ & 0,3 \\
\hline & $830 \mu \mathrm{g} / \mathrm{kg}$ Methidathion* & & & & $0,6 \cdot 10^{6}$ & $0,9 \cdot 10^{5}$ & 6,7 \\
\hline Peach & n.d. & 13 & n.a. & & & & \\
\hline Apple & n.d. & 0 & 2 & & & & \\
\hline Paprika & n.d. & 0 & 0 & & & & \\
\hline Sugar Pea & n.d. & 0 & 1 & & & & \\
\hline Pea & n.d. & 0 & 1 & & & & \\
\hline Pea & n.d. & 1 & 1 & & & & \\
\hline Salad & n.d. & 2 & n.a. & & & & \\
\hline Asparagus & n.d. & 3 & 3 & & & & \\
\hline Asparagus & n.d. & 4 & 7 & & & & \\
\hline Asparagus & n.d. & 0 & 10 & & & & \\
\hline Potato & n.d. & 22 & 9 & & & & \\
\hline Potato & n.d. & 5 & 5 & & & & \\
\hline Gooseberry & n.d. & 13 & 19 & & & & \\
\hline Nisperos & n.d. & 5 & 3 & & & & \\
\hline Plum & n.d. & 8 & 5 & & & & \\
\hline
\end{tabular}

$\mathrm{I}_{\mathrm{ee}}$ : inhibition of electric eel AChE; $\mathrm{I}_{\text {hu }}$ : inhibition of human AChE; ki: bimolecular rate constant of AChE inhibition; n.d.: nothing detected; n.a.: not analyzed. * ki values refer to oxidized forms of organophosphates 
[1] : P. Herzsprung, Methodische Grundlagen des Nachweises und der Bestimmung von insektiziden Phosphorsäureestern und Carbamaten im Wasser mittels Cholinesterasehemmung, Dissertation TU München 1991.

[2]: F. Villatte. V. Marcel, S. Estrada-Mondaca, D. Fournier, Engineering sensitive acetylcholinesterase for detection of organophosphate and carbamate insecticides, Biosensors \& Bioelectronics 13 (1998) 157. 
Table 7: Infant food analysis

\begin{tabular}{|c|c|c|c|c|c|}
\hline Infant food sample & $\mathrm{I}_{\mathrm{ee}}[\%]$ & $\mathrm{R}_{\mathrm{ee}}[\%]$ & $\mathrm{I}_{\mathrm{hu}}[\%]$ & $\mathrm{R}_{\mathrm{hu}}[\%]$ & GC/LC-MS \\
\hline Banana-tangerine-pear (Jul01) & 5 & 0 & 10 & 68 & $20 \mu \mathrm{g} / \mathrm{kg}$ Pirimicarb \\
\hline (Germany) & & & & & $50 \mu \mathrm{g} / \mathrm{kg}$ Ethiofencarb \\
\hline Banana-tangerine-pear (Jun00) & n.a. & & 0 & 0 & n.a. \\
\hline \multirow[t]{2}{*}{ Fruit-salad (Germany) } & 6 & 79 & 9 & 59 & $10 \mu \mathrm{g} / \mathrm{kg}$ Carbaryl \\
\hline & & & & & $6 \mu \mathrm{g} / \mathrm{kg}$ Metalaxyl \\
\hline Pineapple-banana (Spain) & 13 & 74 & 5 & 50 & $4 \mu \mathrm{g} / \mathrm{kg}$ Metalaxyl \\
\hline Peach-maracuja (Germany) & 7 & 97 & 2 & 100 & n.d. \\
\hline Peach-mango (Poland) & 20 & 20 & 8 & 20 & $1 \mu \mathrm{g} / \mathrm{kg}$ Carbaryl \\
\hline Carrot (Poland) & 8 & 59 & 8 & 50 & n.d. \\
\hline \multirow[t]{2}{*}{ Mixed fruits (Spain) } & 15 & 29 & 16 & 30 & $4 \mu \mathrm{g} / \mathrm{kg}$ Methiocarb \\
\hline & & & & & 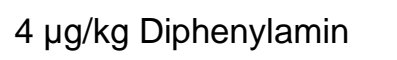 \\
\hline Banana-peach-apple (Germany) & 11 & 19 & 9 & 25 & $2 \mu \mathrm{g} / \mathrm{kg}$ Carbaryl \\
\hline \multirow[t]{4}{*}{ Apricot-yoghurt (Germany) } & 12 & 47 & 6 & 33 & $2 \mu \mathrm{g} / \mathrm{kg}$ Methiocarb \\
\hline & & & & & $2 \mu \mathrm{g} / \mathrm{kg}$ Myclobutanil \\
\hline & & & & & $1 \mu \mathrm{g} / \mathrm{kg}$ Piperonylbutoxid \\
\hline & & & & & $3 \mu \mathrm{g} / \mathrm{kg}$ Iprodion \\
\hline Apricot-pear (Germany) & 15 & 30 & 6 & 40 & $3 \mu \mathrm{g} / \mathrm{kg}$ Methiocarb \\
\hline Apple-peach (Poland) & 30 & 2 & 5 & 0 & n.d. \\
\hline \multirow[t]{2}{*}{ Peaches (USA) } & 12 & 21 & 13 & 13 & 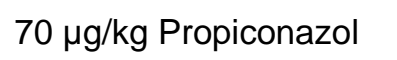 \\
\hline & & & & & $20 \mu \mathrm{g} / \mathrm{kg}$ Esfenvalerat \\
\hline Banana (USA) & 27 & 50 & 29 & 26 & $1 \mu \mathrm{g} / \mathrm{kg}$ Carbaryl \\
\hline Apple-Banana (Germany) & 9 & 0 & 14 & 0 & n.a. \\
\hline Fruit-dessert (Germany) & 6 & 3 & 12 & 0 & n.a. \\
\hline Banana-peach-apple (Germany) & 8 & 3 & 3 & 0 & n.a. \\
\hline Apple (Spain) & 13 & 0 & 1 & 0 & n.a. \\
\hline Williams-Christ-Pear (Germany) & 16 & 0 & 0 & 0 & n.a. \\
\hline \multirow[t]{3}{*}{ Peach-nectar (Spain) } & 0 & 0 & 16 & 7 & $2 \mu \mathrm{g} / \mathrm{kg}$ Paraoxon \\
\hline & & & & & $1 \mu \mathrm{g} / \mathrm{kg}$ Fenhexamid \\
\hline & & & & & $1 \mu \mathrm{g} / \mathrm{kg}$ Azoxystrobin \\
\hline Apple Banana (Germany) & 3 & 100 & 0 & 0 & n.a. \\
\hline Apple (Poland) & 2 & 0 & n.a. & & n.a. \\
\hline Peach in apple (Germany) & 0 & 0 & n.a. & & n.a. \\
\hline Apple rice (Germany) & 0 & 0 & 0 & 0 & n.a. \\
\hline
\end{tabular}

$\mathrm{l}_{\mathrm{ee}}$ : inhibition of electric eel AChE; $\mathrm{I}_{\mathrm{hu}}$ : inhibition of human AChE; $\mathrm{R}_{\mathrm{ee}}$ : reactivation rate of electric eel $A C h E ; R_{h u}$ : reactivation rate of human AChE; n.d.: nothing detected; n.a.: not analyzed. 
Figure 1: Electric eel AChE inhibition caused by different paraoxon concentrations; direct incubation in peach infant food (black; $n=7$ ) compared with the incubation in buffer solution (gray)

Figure 2: Electric eel AChE inhibition caused by different paraoxon concentrations; direct incubation in apple infant food (black; $n=6$ ) compared with the incubation in buffer solution (gray) 


\section{References}

Abad, J.M., Pariente, F., Hernandez, L., Abruna, H.D. and Lorenzo, E., 1998. Determination of organophosphorus and carbamate pesticides using piezoelectric biosensors. Analytical Chemistry 70, 2848-2855.

Anastassiades, M., in preparation. Entwicklung schneller Verfahren zur Rückstandsanalytik von Pflanzenschutzmitteln in Obst und Gemüse unter Einsatz der SFE - ein Beitrag zur Beseitigung analytischer Defizite. PhD Thesis, University of Hohenheim, Stuttgart.

Anastassiades, M. and Scherbaum, E., 1997. Multimethode zur Bestimmung von Pflanzenschutz- und Oberflächenbehandlungsmittel-Rückständen in Zitrusfrüchten mittels GC-MSD; Teil1: Theoretische Grundlagen und Methodenentwicklung. Deutsche Lebensmittel-Rundschau 10, 316-27.

Bachmann, T.T., Leca, B., Villatte, F., Marty, J.-L., Fournier, D. and Schmid, R.D., 2000. Improved multianalyte detection of organophosphates and carbamates with disposable multiresidue biosensors using recombinant mutants of Drosophila acetylcholinesterase and artificial neural networks. Biosensors \& Bioelectronics 15, 193-201.

Bachmann, T.T. and Schmid, R.D., 1999. A disposable, multielectrode biosensor for rapid simultaneous detection of the insecticides paraoxon and carbofuran at high resolution. Analytica Chimica Acta 401, 95-103.

Chambers, H.W., 1992. In: Chambers, J.E. and Levi, P.E. (Eds.) Organophosphates - Chemistry, Fate, and Effects. Academic Press, San Diego, USA, p. 3-17.

Dencker, L. and Ericsjsson, P., 1998. Susceptibility in utero and upon neonatal exposure. Food Additives and Contaminants 15 (suppl), 37-43.

EC (European Communities), 1997. Council Directive 97/57/EC of Sept 22, 1997 establishing Annex VI to Directive 91/414/EEC concerning the placing of plant protection products on the market. Official Journal of the European Communities L265, 87-109.

EC (European Communities), 1999. Commission Directive 1999/50/EC of 25 May 1999 amending Directive 91/321/EEC on infant formulae and follow-on formulae. Official Journal of the European Communities L 139, 29-31. 
Evtugyn, G.A., Budnikov, H.C. and Nikolskaya, E.B., 1996. Influence of surfaceactive compounds on the response and sensitivity of cholinesterase biosensors for inhibitor determination. Analyst 121, 1911-1915.

EWG (Environmental Working Group), 1995. Pesticides in Baby Food. Washington D.C., USA.

FAOSTAT, 1995. Database on Pesticide Consumption, Food and Agriculture Organization of the United Nations, Statistical Analysis Service, Rome, Italy.

FQPA, 1996. The Food Quality Protection Act. US Pub. L. 104-170.

Ghindilis, A.L., Morzunova, H.C., Barmin, A.V. and Kurochkin, I.N., 1996. Potentiometric biosensors for cholinesterase inhibitor analysis based on mediatorless bioelctrocatalysis. Biosensors \& Bioelectronics 11, 837-880.

Guilbault, G.G. and Ngeh-Ngwainbi, J., 1988. In: Guilbault GG, Mascini M (Eds.) Analytical Uses of Immobilized Biological Compounds for Detection, Medical and Industrial Uses. Reidal, Dordrecht, The Netherlands, p. 187.

Jeyaratnam, J., 1990. Pesticides poisoning: as a major global health problem. World Health Statistics Quarterly 43, 139-44.

Karalliedde, L., 1999. Organophosphorus poisoning and anaesthesia. Anaesthesia 54, 1073-88.

Koletzko, B., Aggett, P.J., Agostoni, C., Baerlocher, K., Bresson, J.-L., Cooke, R.J., Desci, T., Deutsch, J., Janda, J., Manz, F., Moya, M., Rigo, J. and Socha, J., 1999. Pesticides in dietary foods for infants and young children - Report of the Working Group on Pesticides in Baby Foods of the European Society for Paediatric Gastronenterology, Hepatology and Nutrition (ESPGHAN). Archives of Disease in Childhood 80, 91-92.

Larsen, J.C. and Pascal, G., 1998. Workshop on the applicability of the ADI to infants and children: consensus summary. Food Additives and Contaminants 15 (suppl), 1-9.

Makower, A., Barmin, A., Morzunova, T., Eremenko, A.V., Kurochkin, I., Bier, F. and Scheller, F., 1997. Affinity enzymometric assay for detection of organophosphorus compounds. Analytica Chimica Acta 357, 13-20.

Martinez, C.R., Gonzales, R.E., Moran, A.M.J. and Mendez, H.J., 1992. Sensitive method for the determination of organophosphorus pesticides in fruits and surface waters by high-performance liquid chromatography with ultraviolet detection. Journal of Chromatography 607, 37-45. 
Mionetto, N., Marty, J.L. and Karube, I., 1994. Acetylcholinesterase in organic solvents for the detection of pesticides: Biosensor application. Biosensors \& Bioelectronics 9, 463-470.

Nunes, G.S., Barcelo, D., Grabaric, B.S., Diaz-Cruz, J.M. and Ribeiro, M.L., 1999. Evaluation of highly sensitive amperometric biosensor with low cholinesterase charge immobilized on a chemically modified carbon paste electrode for trace determination of carbamates in fruit, vegetable and water samples. Analytica Chimica Acta 399, 37-49.

Nunes, G.S., Skladal, P., Yamanaka, H. and Barcelo, D., 1998. Determination of carbamate residues in crop samples by cholinesterase-based biosensors and chromatographic techniques. Analytica Chimica Acta 362, 59-68.

Ostergard, G. and Knudsen, I., 1998. The applicability of the ADI (acceptable daily intake) for food additives to infants and children. Food Additives and Contaminants 15 (suppl), 63-74.

Palchetti, I., Cagnini, A., Carlo, M.D., Coppi, C., Mascini, M. and Turner, A.P.F., 1997. Determination of pesticides in real samples using a disposable biosensor. Analytica Chimica Acta 337, 315-321.

Palleschi, G., Barabei, M., Cremisini, C. and Mascini, M., 1992. Determination of organophosphorus insecticides with choline electrochemical biosensors. Sensors and Actuators B 7, 513-517.

Pogacnik, L. and Franko, M., 1999. Determination of organophosphate and carbamate pesticides in spiked samples of tap water and fruit juices by a biosensor with photothermal detection. Biosensors \& Bioelectronics 14, 569578.

Pylypiw, H.M., 1993. Rapid Gas Chromatographic Method for the Multiresidue Screening of Fruits and Vegetables for Organochlorine and Organophosphate Pesticides. Journal of AOAC International 76, 1369-1373.

Saul, J.S., Zomer, E., Puopolo, D. and Charm, S.E., 1995. Use of a new rapid bioluminescence method for screening organophosphate and $\mathrm{N}$ methylcarbamate insecticides in processed baby food. Journal of Food Protection 59, 303-311.

Scheuplein, R.J., 2000. Pesticides and Infant Risks: Is There a Need for an Additional Safety Margin? Regulatory Toxicology and Pharmacology 31, 26779. 
Schilter, B. and Huggett, A.C., 1998. The ADI as a basis to establish standards for pesticide residues in food products for infants and young children. Food Additives and Contaminants 15 (suppl), 83-9.

Schulze, H., Schmid, R.D. and Bachmann, T.T., 2002. Rapid detection of neurotoxic insecticides in food using disposable acetylcholinesterase-biosensors and simple solvent extraction. Analytical and Bioanalytical Chemistry 372, 268272.

Schulze, H., Vorlová, S., Villatte, F., Bachmann, T.T. and Schmid, R.D., in press. Design of Acetylcholinesterases for Biosensor Applications. Biosensors \& Bioelectronics.

Skladal, P. and Mascini, P., 1992. Sensitive detection of pesticides using amperometric sensors based on cobalt phthalocyanine-modified composite electrodes and immobilized cholinesterases. Biosensors \& Bioelectronics 7 , 335-343.

Skladal, P., Nunes, G.S., Yamanaka, H. and Ribeiro, M.I., 1997. Detection of carbamate pesticides in vegetable samples using cholinesterase-based biosensors. Electroanalysis 9, 1083-1087.

Villatte, F., Marcel, V., Estrada-Mondaca, S. and Fournier, D., 1998. Engineering sensitive acetylcholinesterase for detection of organophosphate and carbamate insecticides. Biosensors \& Bioelectronics 13, 157-164. 